\title{
AVALIAÇÃO DE PROPRIEDADES MECÂNICAS E ELÉTRICAS DE NANOCOMPÓSITOS DE NANOTUBOS DE CARBONO EM MATRIZ DE FLUORELASTÔMERO
}

\author{
M. MAKIYAMA ${ }^{1}$ e R. G. ARAÚJO ${ }^{1}$ \\ ${ }^{1}$ Centro Universitário Tupy - UNISOCIESC \\ E-mail para contato: araujo@ sociesc.org.br
}

\begin{abstract}
RESUMO - O fluorelastômero é um polímero que se destaca entre as borrachas de aplicação industrial pela resistência térmica e química, podendo ser utilizado em aplicações de exposição contínua em temperaturas entre -40 e $204^{\circ} \mathrm{C}$. Entretanto, a resistência ao rasgamento deste material é significativamente reduzida em temperaturas elevadas, o que causa aumento do descarte de peças defeituosas que se rompem na extração do molde a quente. Nanotubos de carbono são nanopartículas que vêm despertando interesse para utilização em compósitos poliméricos devido ao potencial de reforço de propriedades mecânicas e modificação de condutividade elétrica. O objetivo do trabalho foi avaliar a influência do teor de nanotubos sobre as propriedades mecânicas e condutividade elétrica de compósitos. Nanocompósitos, com teores de nanotubos entre 0,5 e $3,0 \% \mathrm{~m}$, foram obtidos pelo método de mistura com o polímero fundido, alcançandose um aumento de até $25 \%$ na resistência ao rasgamento e $70 \%$ na deformação por compressão.
\end{abstract}

Palavras-Chave: Fluorelastômero; Nanotubos de carbono; Nanocompósito;

\section{INTRODUÇÃO}

Nos últimos anos o desenvolvimento da área de nanotecnologia teve avanços significativos, principalmente pelo potencial de obtenção de novos produtos e novas propriedades para produtos já existentes, trazendo benefícios para diversas áreas como eletrônica, medicina, energia, aeroespacial, saúde, segurança, agricultura e materiais (Antonucci et al.,2003).

Os nanotubos de carbono (NTC) foram descobertos em 1991 por Sumio Ijima (Ijima, 1991) e desde então, muita atenção vem sendo dedicada a este material devido ao seu grande potencial de aplicação e extraordinárias propriedades físicas, químicas e elétricas (Antonucci et al.,2003). Muitos estudos de nanocompósitos envolvendo nanotubos de carbono tem sido realizados em função destas propriedades (Gardea e Lagoudas, 2014; Jin et al., 2014).

Partículas com dimensões nanométricas, normalmente fibrosas ou em forma de lamelas e esferas vem sendo incorporadas a matrizes poliméricas para obtenção de materiais diferenciados. Nanocompósitos poliméricos têm se mostrado vantajosos em relação aos compósitos convencionais, 


\section{9 a 22 de outubro de 2014 \\ Florianópolis/SC}

uma vez que a adição de pequenas quantidades de nanopartículas ocasiona uma alteração significativa nas propriedades finais do polímero matriz. Este fato é atribuído à elevada área superficial das partículas, resultando em uma área de interface com a matriz muito maior em comparação com os compósitos convencionas. Compósitos de matriz polimérica são exemplos clássicos de materiais utilizados pelas indústrias visando melhoras nas propriedades mecânicas e químicas dos componentes (Ajayan et al., 2003).

Fluorelastômeros (FKM) são polímeros altamente resistentes após sua completa vulcanização, podendo ser utilizado para fabricação de produtos aplicados em uma ampla faixa de temperatura, entre $-40^{\circ} \mathrm{C}$ e $204^{\circ} \mathrm{C}$. Além disto, são resistentes a uma grande variedade de produtos químicos como solventes e combustíveis e apresentam alta resistência à oxidação atmosférica, radiação solar e ozônio. As principais aplicações dos fluorelastômeros são peças automotivas, tais como gaxetas, retentores, mangueiras de combustíveis e vedações (Brydson, 2000).

O tempo para a total vulcanização (cura) dos fluorelastômeros pode chegar à 24h, sendo inviável a permanência do composto por tanto tempo em uma linha de produção. Para solucionar este problema, o processo industrial evolve uma vulcanização parcial do composto, durante um tempo suficiente para que o elastômero moldado assuma a forma do produto, e em seguida este é retirado do molde e levado a uma estufa para complementação da cura. Como no momento da extração do molde o elastômero não está completamente vulcanizado, é muito comum haver rasgamento dos produtos, o que eleva os custos de produção, tanto pela perda do produto que não pode ser reprocessado, quanto pelo tempo de utilização dos equipamentos e mão de obra. Fluorelastômeros são materiais relativamente caros, podendo custar até cinco vezes mais que um produto fabricado com outros elastômeros.

O objetivo desse trabalho foi avaliar a influência do teor de nanotubos de carbono sobre as propriedades mecânicas e elétricas de nanocompósitos Fluorelastômero/NTC. Teores de nanotubos entre 0,5 e 3,0 \% foram incorporados em um composto de fluorelastômero, contendo negro de fumo, óxido de cálcio, óxido de magnésio, carbonato de cálcio e agentes de vulcanização. A incorporação dos nanotubos e demais aditivos foi realizada em misturadores de rolo com posterior vulcanização em moldes de compressão a quente e pós-cura em estufa. As propriedades mecânicas avaliadas foram resistência ao rasgo, resistência à tração e deformação permanente à compressão. Determinou-se ainda a resistividade elétrica volumétrica dos nanocompósitos através do método de ensaio de duas pontas.

\section{EXPERIMENTAL}

\subsection{Materiais}

Para a preparação dos nanocompósitos foram utilizados nanotubos de carbono de parede múltipla, com diâmetro externo entre 20 e $30 \mathrm{~nm}$ e comprimento entre 10 e $30 \mu \mathrm{m}$, funcionalizados com grupos carboxila, fornecidos por Cheap Tubes INC., Vermont (EUA). O teor de grupos carboxila nos nanotubos foi de $1,2 \%$ em massa, segundo o fabricante. 
O fluorelastômero utilizado para nesse trabalho foi o Dyneon ${ }^{\circledR}$ FC-2174, um copolímero de fluoreto de vinilideno e hexafluorpropileno, fornecido pela $3 \mathrm{M}$ do Brasil. A escolha desse elastômero deu-se pela boa relação custo benefício, visto que possui baixa viscosidade, o que facilita a injeção no interior da cavidade, e rápida vulcanização. Após a vulcanização completa, apresenta resistência à tração de 16,9 MPa, módulo de elasticidade de 7,2 MPa e deformação na ruptura de $180 \%$, segundo o fabricante.

Na preparação do composto elastomérico foram utilizados os seguintes aditivos: negro de fumo (Sevarcarb MT990) fornecido pela Fragon, óxido de magnésio (Oximag TN-6) fornecido pela Bushle \& Lepper, óxido de cálcio (Cobrascal) e carbonato de cálcio natural, ambos fornecidos pela Auriquímica.

\subsection{Preparação dos nanocompósitos}

As formulações dos nanocomósitos foram preparadas em misturador de cilindro, modelo BML 150 fabricado pela Luxor, com diâmetro e comprimento do cilindro de $150 \mathrm{~mm}$ e $300 \mathrm{~mm}$. Foram obtidas formulações a partir de $200 \mathrm{~g}$ de fluorelastômero com as composições descritas na tabela 1.

Tabela 1 - Composição das formulações dos nanocompósitos em pcr (partes por cem de resina)

\begin{tabular}{c|c|c|c|c|c}
\hline \multirow{2}{*}{ Componente } & \multirow{2}{*}{ Função } & \multicolumn{3}{|c}{ Formulações (quantidade em pcr) } \\
\cline { 3 - 6 } & & Base & NC05 & NC15 & NC30 \\
\hline Fluorelastômero (Dyneon FC-2174) & Elastômero & 100 & 100 & 100 & 100 \\
\hline Negro de fumo & Carga & 8 & 8 & 8 & 8 \\
\hline Óxido de magnésio & $\begin{array}{c}\text { Capturador } \\
\text { de Fluoretos }\end{array}$ & 3 & 3 & 3 & 3 \\
\hline Carbonato de cálcio & Carga & 6 & 6 & 6 & 6 \\
\hline Óxido de cálcio & Auxiliar & 8 & 8 & 8 & 8 \\
\hline Nanotubos de Carbono & $\begin{array}{c}\text { Partículas } \\
\text { de Reforço }\end{array}$ & - & 0,5 & 1,5 & 3,0 \\
\hline
\end{tabular}

O processo de mistura teve início com a mastigação do elastômero por 2 min e em seguida foram adicionados os demais aditivos em sequência negro de fumo, o carbonato de cálcio, óxido de cálcio, óxido de magnésio e nanotubos de carbono. Após a adição de cada componente, os materiais foram mastigados pelo cilindro até sua total incorporação.

A pré-vulcanização do material e moldagem dos corpos de prova foram realizadas em prensa hidráulica, a uma temperatura de $170^{\circ} \mathrm{C}$ e pressão de 210 bar por cerca de 120 s. Não foi realizada a pós-cura do material pois o intuito do trabalho foi avaliar as propriedades mecânicas nas condições de cura incompleta, tas como o material é extraído do molde 


\section{9 a 22 de outubro de 2014 \\ Florianópolis/SC}

\subsection{Caracterização dos nanocompósitos}

Para avaliar a influência dos nanotubos de carbono sobre a processabilidade do composto elastomérico, amostras das formulações não vulcanizadas foram analisadas em reômetro de torque, modelo MDR 2000 fabricado pela Monsanto. As análises foram realizadas com frequência de 100 cpm (Compressible Packing Model), amplitude de deformação de $1^{\circ}$ e temperatura de $100{ }^{\circ} \mathrm{C}$, sendo determinados os quatro parâmetros principais: torque mínimo (ML), que mede a fluidez do composto antes da sua vulcanização; tempo de início de cura (TS2) que é determinado pelo aumento do torque em 1 dN.m, para manter a deformação; tempo ideal de cura (TC90) correspondente a 90\% de vulcanização do composto e torque máximo $\mathrm{MH}$, que está diretamente relacionado ao grau de vulcanização.

O ensaio de deformação permanente por compressão foi realizado em corpos de prova vulcanizados, conforme norma ASTM D395. Corpos de prova retangulares com espessura em torno de $12 \mathrm{~mm}$ foram fixados em um dispositivo de ensaio e deformados por compressão em $25 \%$ (deformação aplicada - $\mathrm{D}_{\mathrm{ap}}$ ). Nessas condições, os corpos de prova foram submetidos a uma temperatura de $150^{\circ} \mathrm{C}$ por $70 \mathrm{~h}$. Após resfriamento natural dos corpos de prova foi determinada a deformação final $\left(\mathrm{D}_{\mathrm{f}}\right)$. A deformação permanente $\left(\mathrm{D}_{\mathrm{p}}\right)$ foi calculada utilizando a equação 1 .

$$
D_{p}=\left(D_{f} / D_{a p}\right) 100
$$

O ensaio de tração foi realizado em máquina universal de ensaios, modelo DL2000 fabricado pela EMIC, com célula de carga de $100 \mathrm{kN}$ e velocidade de ensaio de $500 \mathrm{~mm} / \mathrm{min}$, conforme norma ASTM D412. O ensaio de rasgamento foi realizado conforme norma ASTM D624, na mesma máquina universal de ensaios, com célula de carga de $100 \mathrm{kN}$ e velocidade de ensaio de $500 \mathrm{~mm} / \mathrm{min}$ a temperatura ambiente. Corpos de prova vulcanizados do tipo $\mathrm{C}$ (com ângulo de $90^{\circ}$ ) foram ensaiados até a ruptura, sendo determinada como resistência ao rasgamento o valor máximo de tensão aplicada.

A resistividade elétrica volumétrica dos compostos foi determinada pelo método duas pontas, utilizando um eletrômetro da Keithley, modelo 6517A com fonte de corrente contínua. Neste método a amostra foi colocada em um dispositivo porta-amostra (acessório 8009-Keithley) ligado ao eletrômetro sendo aplicada uma tensão entre 1 e 100 Volts e determinada a corrente elétrica que percorreu a amostra.

\section{RESULTADOS E DISCUSSÃO}

A Tabela 2 apresenta os resultados das análises de reometria de torque. Nota-se que tanto o torque mínimo $(\mathrm{ML})$ quanto o torque máximo $(\mathrm{MH})$ sofreram um aumento progressivo a medida que aumenta-se o teor de nanotubos de carbono no composto. Estes resultados estão de acordo com Mariano et al. (2008), e devem ser atribuídos à característica reforçante dos nanotubos por apresentarem uma boa interação com a matriz polimérica, restringindo a mobilidade molecular e consequentemente a viscosidade. $\mathrm{O}$ aumento gradual de ML com o aumento do teor dos nanotubos sugere que houve uma boa dispersão das nanopartículas na matriz do elastômero. 
Por outro lado, os valores de tempo inicial de cura (TS2) e tempo ideal de cura (TC90) das formulações contendo nanotubos de carbono mantiveram-se praticamente inalterados em comparação à formulação base. Tal resultado demonstra que o processo de vulcanização independe da presença de nanotubos no intervalo de teor de adição estudado. A aceleração do processo de vulcanização acontece por meio de ativadores que na sua grande maioria, possuem grupos funcionais amínicos. Como os nanotubos de carbono utilizados são funcionalizados com grupos carboxila $-\mathrm{COOH}$, sugere-se que esse tipo de grupo funcional não interfere na vulcanização.

Tabela 2: Resultados das análises de reometria de torque

\begin{tabular}{c|c|c|c|c}
\hline \multirow{2}{*}{ Formulações } & \multicolumn{4}{|c}{ Propriedades } \\
\cline { 2 - 5 } & ML (dN.m) & TS2 (s) & TC90 (s) & MH (dN.m) \\
\hline Base & 1,23 & 100 & 159 & 13,95 \\
\hline NC05 & 1,26 & 94 & 158 & 13,80 \\
\hline NC15 & 1,31 & 102 & 163 & 14,46 \\
\hline NC30 & 1,34 & 97 & 169 & 14,58 \\
\hline
\end{tabular}

O comportamento da deformação permanente por compressão (DPC) em relação ao teor de nanotubos de carbono no compósito é apresentada na Figura 1. Pode-se observar que o aumento do teor de nanotubos na formulação aumenta o valor do DPC, isto é, a borracha se deforma mais ao receber o reforço dos nanotubos de carbono. O aumento chega a ser de mais de $70 \%$ na deformação obtida para a formulação contendo 3 pcr de nantubos em relação à formulação sem nanotubos. Este comportamento era esperado uma vez que cargas reforçantes tendem a reduzir a resiliência do elastômero. Entretanto, amostras das formulações com 0,5 e 1,5 pcr de nanotubos apresentaram valores de DPC semelhantes, indicando que o teor de 1,5 pcr pode ser adequado para fabricação de produtos reforçados sem grande perda de resisliência.

Por sua vez, a resistência ao rasgamento dos compostos aumenta gradativamente com o aumento do teor de nanotubos de carbono presente, conforme mostra a Figura 2. A tensão necessária para rompimento do corpo de prova da formulação contendo 3 pcr de nanotubos foi elevada em $24,9 \%$ em comparação com a formulação isenta de nanotubos. Nota-se ainda que a adição de 0,5 pcr de nanotubos induziu ao aumento em $14,6 \%$ a resistência ao rasgamento. O aumento na resistência ao rasgamento sugere que os nanotubos de carbono interagem com as cadeias do elastômero antes e após a vulcanização, contribuindo com suas propriedades mecânicas. 


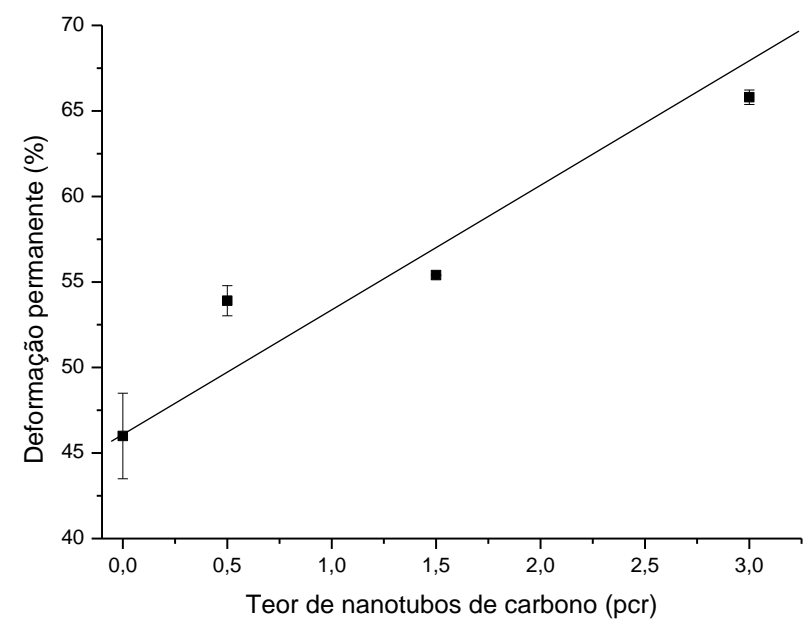

Figura 1 - Comportamento da deformação permanente dos nanocmpósitos em relação ao teor de nanotubos de carbono

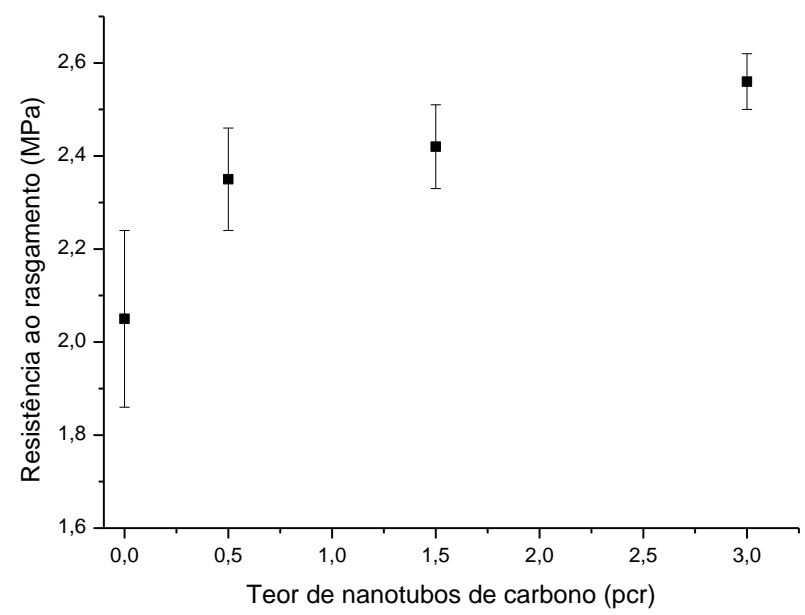

Figura 2 - Resistência ao rasgamento dos nanocompósitos em relação ao teor de nanotubos

A Figura 3 mostra que houve um aumento gradual no valor da resistência à tração com o aumento do teor de nanotubos de carbono no composto, atingindo $25 \%$ de aumento na formulação com 3,0 pcr em comparação com a formulação sem nanotubos. Além disto, módulo de elasticidade dos compostos, determinado em $100 \%$ de alongamento (Figura 4), também apresentou uma elevação gradativa com relação ao teor de nanotubos no composto, atingindo um aumento de 46,3\% da 
formulação com 3 pcr em relação à formulação isenta de nanotubos. Pode-se afirmar que o módulo e a resistência à tração aumentaram e o alongamento se manteve constante, demonstrando que houve reforço do material com a adição de nanotubos de carbono, sem perda de tenacidade.

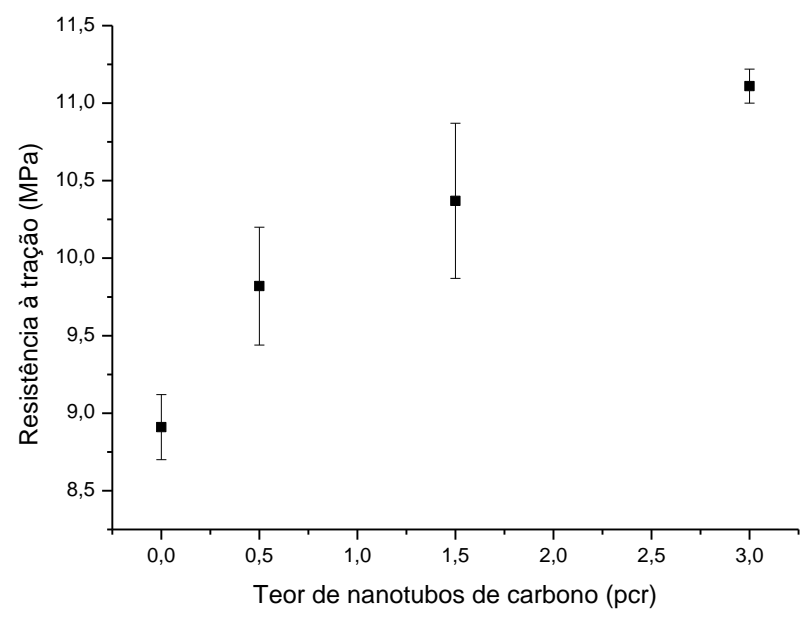

Figura 3 - Resistência à tração dos nanocompósitos em relação ao teor de nanotubos de carbono

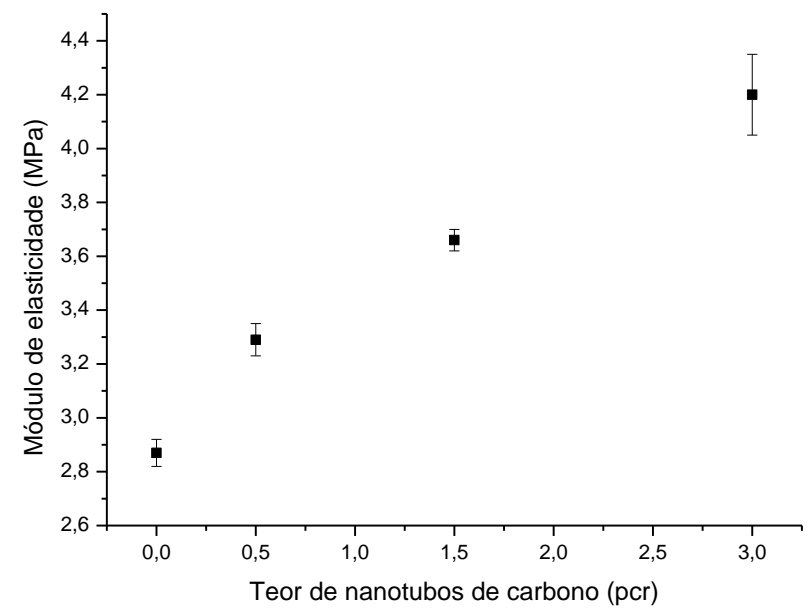

Figura 4 - Módulo de elasticidade dos nanocompósitos em relação ao teor de nanotubos de carbono

A resistividade elétrica volumétrica dos nanocompósitos com nanotubos de carbono manteve-se na mesma ordem de grandeza, $8,6 \times 10^{10} \Omega \mathrm{cm}$, em relação ao composto sem nanotubos, sugerindo que o limiar de percolação da resistividade elétrica desse tipo de nanocompósito se encontra acima da 
faixa de teor de nanotubos estudado. Esse comportamento difere dos resultados obtidos por Araujo e Pires (2013) que para nanocompósitos de PVC com nanotubos de carbono determinaram um limiar de percolação em $0,4 \%$ m.

\section{CONCLUSÃO}

A adição de nanotubos de carbono em compostos de fluorelastômeros mostrou-se vantajosa uma vez que as propriedades mecânicas avaliadas foram elevadas em relação à formulação isenta de nanotubos, sem perdas na processabilidade ou tenacidade do material. Por outro lado, a resistividade elétrica do elastômero não foi modificada pela presença de nanotubos nos teores estudados, sugerindo que há necessidade de adição de teores superiores.

\section{AGRADECIMENTOS}

Os autores agradecem a Empresa Caribor Tecnologia da Borracha Ltda e ao departamento de Engenharia Química da UNISOCIESC pelo apoio ao trabalho.

\section{REFERÊNCIAS}

ANTONUCCI, V.; HSIAO, K.; ADVANI, S.G. Advanced Polymeric Materials: Structures and Properties Relationships. New York: CRC Press, 2003.

AJAYAN, P. M.; SCHADLER, L. S.; BRAUN, P. V. Nanocomposite science and technology. Weinheim [Great Britain]: Wiley-VCH, 2003.

ARAUJO, R.G.; PIRES, A.T.N. Nanocompósitos PVC/Nanotubos de Carbono: Avaliação da Resistividade Elétrica e Efeito do Solvente nas Propriedades Térmicas. Polímeros: Ciência e Tecnologia. v. 23, p. 839-843, 2013.

BRYDSON, J. A. Plastics Materials. 7th. ed. Oxford: Butterworth Heinemann, 2000

GARDEA, F. LAGOUDAS, D.C. Characterization of electrical and thermal properties of carbon nanotube/epoxy composites. Comp. Part B: Eng., v. 56, p. 611-620, 2014.

IIJIMA, S. Helical microtubules of graphitic carbon. Nature, v. 354, p. 56-58, 1991.

JIN, S.Y.; YOUNG, R.J., EICHHORN, S.J. Hybrid carbon fibre-carbon nanotube composite interfaces. Comp. Sci. and Tech., v. 95, p. 114-120, 2014.

MARIANO, R.M.; VISCONTE, L.L.Y.; OLIVEIRA, M.R.L. e RUBINGER, M.M.M. Avaliação de Bis(4-Metilfenilditiocarbimato) Zincato(II) de Tetrabutilamônio como Acelerador em Composições de Borracha Natural. Polímeros: Ciência e Tecnologia, v. 18, nº 4, p. 297-301, 2008. 